\title{
Correction: Rumen-protected conjugated linoleic acid supplementation to dairy cows in late pregnancy and early lactation: effects on milk composition, milk yield, blood metabolites and gene expression in liver
}

Tanja Sigl*1, Gregor Schlamberger ${ }^{1}$, Hermine Kienberger², Steffi Wiedemann¹, Heinrich HD Meyer ${ }^{1}$ and Martin Kaske

\section{Correction}

After publication of this work [1] we realised that some of the values were incorrect in Table 2 Additional file 1 . We have corrected these in the updated table.

\section{Additional material}

Additional file 1 Corrected table 2

\section{Author Details}

'Physiology Weihenstephan, Technische Universitaet Muenchen, Weihenstephaner Berg 3, Freising-Weihenstephan, Germany, 2Bioanalytik, Technische Universitaet Muenchen, Versuchsstation Thalhausen, FreisingWeihenstephan, Germany and ${ }^{3} \mathrm{Clinic}$ for Cattle, University of Veterinary Medicine, Bischofsholer Damm 15, Hannover, Germany

Received: 27 April 2010 Accepted: 20 May 2010

Published: 20 May 2010

\section{References}

1. Sigl T, Schlamberger G, Kienberger H, Wiedermann S, Meyer HHD, Kaske

M: Rumen-protected conjugated linoleic acid supplementation to dairy cows in late pregnancy and early lactation: effects on milk composition, milk yield, blood metabolites and gene expression in liver. Acta Veterinaria Scandinavica 52:16

*Correspondence: sigl@wzw.tum.de

1 Physiology Weihenstephan, Technische Universitaet Muenchen,

Weihenstephaner Berg 3, Freising-Weihenstephan, Germany

Full list of author information is available at the end of the article

Submit your next manuscript to BioMed Central and take full advantage of:

- Convenient online submission

- Thorough peer review

- No space constraints or color figure charges

- Immediate publication on acceptance

- Inclusion in PubMed, CAS, Scopus and Google Scholar

- Research which is freely available for redistribution

Submit your manuscript at www.biomedcentral.com/submit 